\title{
THE LIMITS OF REGULATORY GOVERNANCE
}

The concluding chapter re-assembles the PCP model with the specifications generated by the empirical analyses in chapters $3-5$. Power, capacity, and politicization matter in the two-level compliance game, which plays out across the two stages of EU law making. While power and capacity figure prominently in the literature, the PCP model specifies which conceptualizations are most relevant and how they interact in making noncompliance more or less likely. Moreover, the PCP model introduces politicization as a factor that has been largely neglected in compliance research but is crucial in understanding why some member states comply less than others, why noncompliance has declined over time, and why market-correcting policy is more prone to be violated.

I argue that the PCP model provides for a comprehensive account of variation in noncompliance with EU law across twenty-eight member states, eleven policy sectors, and more than forty years of European integration. Built within a rational institutionalist framework, the model is generalizable enough to explain the politics of noncompliance in areas of EU law not subject to infringement proceedings, as well as in other regional and international organizations. I then propose areas for future research where the PCP model could provide new insights, particularly with regard to the increasing relevance of politicization and the redistributive nature of law beyond the nation state. I conclude by considering the implications of my theoretical arguments and empirical findings for the effectiveness and legitimacy of the EU, and international governance more broadly. The increasing politicization of international trade, security, and climate change policy shows the limits of international regulation in dealing with redistributive issues. 
International institutions lack sufficient tax and spending capacity to engage in meaningful redistribution. At the same time, they increasingly constrain states in making social adjustments to compensate those of their citizens who do not profit from globalization. The rise of nationalist movements and populist parties in Europe and in the US challenging the liberal foundations of Western societies and the international order alike may be the harbingers of post-regulatory politics. States need to tackle redistribution directly and decide who gets what in a transparent and accountable way instead of leaving this decision to independent agencies or the global markets.

\section{The Politics of Noncompliance: Power, Capacity, and Politicization}

The book set out to answer the following research question: Why has noncompliance in the EU not increased, or even decreased since the mid-1990s, despite a growing number of member states with weak compliance capacities and waning enthusiasm for European integration and with EU legislation expanding in sectors that are particularly prone to noncompliance? The research question consists of three empirical puzzles. To solve them, chapter 2 set out the PCP model, which conceptualizes compliance as a two-level game played across two stages. Unlike existing studies, it focuses on three variables that affect both the shaping and the taking of international and EU law. The model combines power and capacity in explaining noncompliance, while also specifying which conceptualizations matter in the shaping and taking of EU law. Finally, the PCP model brings in politicization, which compliance research has largely neglected. Counterintuitively, politicization explains why popular support for the EU increases noncompliance. Politicization also accounts for the declining noncompliance in an ever deeper and wider European Union.

The compliance game starts at the shaping stage. As rational actors, member state governments seek to minimize compliance costs by shaping EU laws according to their policy preferences. They differ, however, in the ability to do so. Rather than economic size or voting power in the Council, it is the Euroscepticism of their population that allows big and small member states alike to negotiate for policy outcomes that incur lower compliance costs on their domestic constituencies. Euroscepticism increases the chances of politicization in the implementation of costly EU laws. The anticipated risk of politicization, which may spill over to other member states, allows the governments of Eurosceptic countries to assert that their hands are tied by domestic opposition and therefore 
to negotiate for legal acts that entail lower compliance costs, to enable them to overcome such opposition. The differing propensity for domestic politicization explains why countries with efficient bureaucracies and similar voting power vary in their noncompliance with EU law, depending on how much their publics support and oppose the EU.

Chapter 3 confirmed the expectations of the PCP model that big, inefficient, and EU-supportive member states are worse compliers than small, efficient, and Eurosceptic member states. Combining power, capacity, and politicization, the PCP model can also explain why equally big and equally small member states substantially differ in their noncompliance with EU law (France versus UK; Denmark versus Luxembourg). Big states have the power to resist compliance with costly EU law, while small states have little choice but to comply. Both differ, however, in their ability to reduce compliance costs at the shaping stage and to cope with costly EU law at the taking stage. Eurosceptic member states, big or small, can tie their hands in negotiating policy outcomes close to their policy preferences. With efficient bureaucracies, they have less difficulty in coping with compliance costs at the taking stage if they have not been able to reduce them at the shaping stage in the first place. The combination of power, capacity, and politicization explains why Italy tops the list of noncompliers. The quality of its bureaucracy is as low as that of Greece or Portugal. So is its ability to reduce compliance costs at the shaping stage. What makes its performance even worse is Italy's power to resist compliance pressure. Denmark's bureaucracy is not only more efficient in both shaping and taking EU law. As one of the most Eurosceptic countries (until recently at least), Denmark holds an advantage, also over other member states with equally efficient bureaucracies and little power of recalcitrance, such as Belgium or Luxembourg. Likewise, big but efficient UK performed better than equally big and efficient Germany because its government could credibly tie its hands to the most Eurosceptic public in the EU, which voted to leave in 2016.

The PCP model can also explain why eastern enlargement, which brought in twelve member states with low administrative capacity that had no possibility to shape the vast part of EU laws they have to comply with, has not reversed the negative trend in noncompliance. Not only do the newcomers have little power to resist compliance costs. Pre-accession assistance and conditionality helped them build the specific administrative capacity to take EU law. Finally, the centralized taking capacity built during the accession phase has shielded the governments of the new member states against the politicization of costly EU laws in their implementation at the domestic level, particularly in the early days of their membership.

Figure C.1 reassembles the PCP model in light of the empirical findings. It is powerful in explaining country variation. Austria is the only member state 


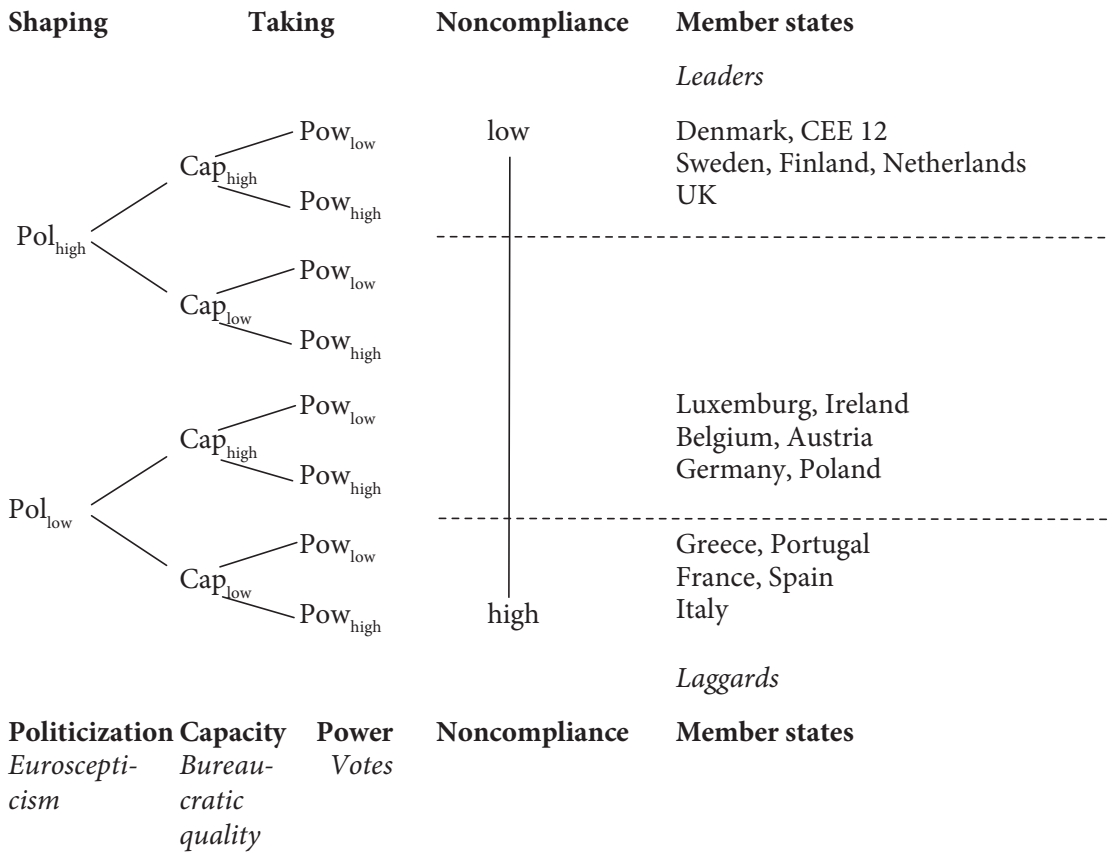

FIGURE C.1. The PCP model reassembled

whose level of noncompliance is lower than expected. Its bureaucratic quality is as high as its power is limited compared to the other Eurosceptic member states that head the list of compliers. Nevertheless, Austria's performance puts it in the middle field, on a par with the more Europhile Belgium and Luxembourg. Politicization is a major part of Austria's noncompliance with EU law (Falkner et al. 2005, 271, 333). Having joined in 1995, the Austrian government has had less opportunity to tie its hands to its Eurosceptic public to shape new EU law, since the EU has increasingly passed amending legislation adopted by the Commission rather than the Council and the EP. Yet this is also the case for Sweden and Finland, which comply much better.

The PCP model not only explains why some states comply less than others. By bringing in EU institutions, it also tackles variation in noncompliance across time and policy sectors, two dimensions that the literature has woefully neglected. While more EU opposition (anticipated politicization) increases the ability of member states to shape EU laws, the actual politicization of costly EU laws renders their taking more difficult. This is the reason why delegated legislation, in whose shaping and taking parliaments have no say either at the European or at the domestic level, is less prone to noncompliance. Likewise, market-correcting 
regulatory policy has a greater propensity of being violated, as its compliance costs are more likely to become politicized at the taking stage.

As suggested by IR theory, temporal variations in noncompliance are driven by changes in international institutions. Yet rather than enforcement, management, or legitimacy, it is the delegated decision-making power of international institutions that allows states to abide (more) with international and EU law. Delegating the adoption of international and EU laws to "regulatory bureaucracies" (Pollack 1997a, 106), such as the European Commission, entails lower compliance costs, which are also less visible to domestic constituencies. On the one hand, states opt for delegation to achieve policy outcomes that otherwise may get caught in time-consuming and complex international negotiations or become politicized at the domestic level (Moravcsik 1998). On the other hand, state principals seek to retain control over their international agents by administrative and oversight procedures (Pollack 1997a). As a result, delegated legislation tends to be secondary legislation amending existing rules and procedures rather than the setting new ones. Moreover, being executive acts, delegated legislation does not involve parliaments. Compliance costs are less visible to the public and therefore less likely to become politicized in implementation and enforcement at the domestic level. This is why noncompliance has decreased since the mid1990s. Chapter 4 demonstrated that with the completion of the Internal Market, the EU started to pass more and more amending legislation, whose adoption is delegated to the Commission. Despite a growing body of EU law and an increasing number of member states that have to comply with it, noncompliance has declined.

As regards the third puzzle, violations of EU law are concentrated in a handful of policy sectors. Market-correcting policy is more frequently violated because it entails higher compliance costs that are more likely to become politicized. Unlike distributive and redistributive policy, regulatory policy incurs costs at the taking rather than at the shaping stage. Therefore, states are more likely to agree on regulatory as opposed to redistributive policy-they only have to face the costs when it comes to implementing and enforcing their agreements (Majone 1993, 1994). This explains why international and EU law tends to be regulatory rather than redistributive. At the same time, the regulatory nature makes international and EU law more prone to noncompliance, particularly when it seeks to protect and advance citizen rights. Chapter 5 validated the argument that EU laws that seek to harmonize regulatory standards to prevent market failure and correct politically undesired market outcomes are costlier than EU laws that aim at opening markets for foreign competition. To protect the environment or consumer and citizens' rights, member state government have not only to refrain from collecting tariffs and taxes. They have to enact or change existing legislation, which 
requires administrative capacity. Moreover, market actors have to often make costly adjustments to their behavior to comply with EU social and environmental standards. Accordingly, market-correcting law is more demanding on member states' enforcement capacity. Also, its compliance costs tend to be more visible and salient, making domestic opposition more likely.

In sum, the PCP model combines factors privileged by different compliance approaches and thereby provides for a comprehensive explanation of noncompliance in the EU regarding variation across countries, time, and policy sectors. Instead of treating power, capacity, and EU support as alternative explanations, the PCP model integrates them as complementary accounts of member state noncompliance. Drawing on concepts of general compliance theories and testing alternative conceptualizations allowed me to accommodate many of the explanatory factors considered in EU research without inflating the PCP model.

\section{The Politics of Noncompliance: Europe and Beyond}

The book develops a model of noncompliance with EU law whose enforcement and, increasingly, whose adoption the member states have delegated to the European Commission and the ECJ. This raises the questions of whether the PCP model also applies to areas that are not subject to infringement proceedings, and whether it travels to other international institutions where states largely control the enforcement and management of compliance.

\section{From Market to Economic and Political Integration}

The theoretical arguments of this book are based on a comprehensive empirical analysis of noncompliance with EU law. The Berlin Infringement Database covers thousands of violations of EU laws that form the core of the European integration project to which infringement proceedings apply. Article 258 TFEU entitles the European Commission to bring legal action against member states for failing to fulfill their obligations under EU law. There are three areas of EU law, however, that are not subject to the infringement proceedings of Article 258: competition law, economic and monetary policy, and the fundamental values.

First, Article 105 TFEU grants the Commission direct and exclusive enforcement authority to ensure free and fair competition in the Internal Market. This entails extensive investigative powers, including the authority to carry out dawn raids on the premises of suspected undertakings and private homes and vehicles in the member states (cf. Jones and Sufrin 2016). ${ }^{1}$ These exceptional powers also 
show in the possibility of the Commission to refer cases to the ECJ without opening infringement proceedings if member states refuse to comply with its decision. Since competition law is treaty law, member states have no shaping possibilities to reduce compliance costs. In the taking of a Commission decision, however, capacity and politicization should still matter. What makes the case interesting is the attempt of the Commission to extend its enforcement authority for competition law to areas in which it has only limited competencies, such as taxation. In the summer of 2016, the Commission sought to force the Irish government to collect more than $€ 13$ billion in taxes from Apple. ${ }^{2}$ Ireland refused to comply, so the Commission referred the case to the ECJ. The Irish government claimed that the Commission had overstepped its competencies by dictating tax laws and imposing them on a tax deal of twenty-five years ago. The Commission contended that Ireland had granted Apple tax credits that were far too generous (less than 1 percent) and therefore amounted to state subsidies. It withdrew the case in October 2018 after the Irish government had caved in and collected the money from Apple. ${ }^{3}$

Second, while the Commission enjoys extraordinary powers to enforce competition law, it has only a subsidiary role in guarding the EMU. The member states have created the Stability and Growth Pact and the Excessive Deficit Procedure Protocol to impose fiscal discipline and prevent the building up of unsustainable national deficits. To ensure compliance with the limits on budget deficit (3 percent of GDP) and state debt (60 percent of GDP) set by the convergence criteria of the Maastricht Treaty, EU member states have to submit every year a compliance report for the scrutiny and evaluation of the Commission and the Council of Ministers. While the Commission is in charge of monitoring, sanctions have to be decided by the member states, which they considered in only three cases (Portugal, Spain, and Italy) and have never actually imposed so far. ${ }^{4}$ Overall, the excessive deficit procedure is at best a soft policy tool for monitoring budget reforms rather than a hard mechanism for enforcing budgetary discipline on the member states. ${ }^{5}$

Third, the reluctance of the member states to have the EU interfere with core state powers (Genschel and Jachtenfuchs 2016) also explains why infringement proceedings do not apply to violations of fundamental values laid down in Article 2 TEU. The deterioration of democracy and the rule of law in Hungary since 2010, Romania in 2012, and in Poland since 2015 violates the liberal democratic founding values of the EU (Sedelmeier 2014; Keleman 2017; von Bogdandy and Sonnevend 2015). Yet the member states have refused to make the Commission the sole guardian of those values. While accession candidates are subject to strict political conditionality, the Commission has limited powers to monitor and enforce compliance with human rights, democracy, and the rule of law within 
the EU (van Hüllen and Börzel 2015). In response to the participation of rightwing populist parties in member state governments (Alianza Nazionale in Italy, Freiheitliche Partei Österreich in Austria), the Treaty of Amsterdam established with Article 7 a sanction mechanism, which provides for the suspension of membership rights in the event of a "serious and persistent breach" of EU values. The Treaty of Lisbon amended Article 7, allowing action against a "clear risk" of a breach (Sadurski 2012).

The design of Article 7 renders it a rather blunt instrument, though. The Commission and the member states consider it an instrument of last resort or a "nuclear option." They have been reluctant to use it as means to prevent a major crisis at an early stage of eroding compliance (Jakab and Kochenov 2016). The Commission, the European Parliament, and one-third of the member states can initiate the Article 7 procedure. Any decision on a risk and the adoption of recommendations addressed to the offending government requires a fourfifths majority in the European Council and a simple majority in the European Parliament. A breach has to be determined by unanimity (minus one) in the European Council and approved by simple majority in the EP. Sanctions have to be supported by a qualified majority in the Council. The majority requirements in Council and Parliament have so far proven an insurmountable institutional hurdle for the application of Article 7. National governments and members of the European Parliament alike seek to protect members of their respective European party family (Sedelmeier 2014). To lower the bar, the Commission adopted a new framework in 2014 to address systemic threats to the rule of law in the member states (Kochenov and Pech 2016). ${ }^{6}$ The rule-oflaw framework is based on dialogue rather than punishment. If the framework fails to produce a solution, Article 7 TEU is to be triggered. The Commission activated the framework for the first time against the newly elected Polish government, seeking to counteract its attempts to undermine the independence of the Polish Constitutional Tribunal and the public broadcasters. ${ }^{7}$ Since Polish authorities refused to cooperate on its opinions and recommendations, the Commission invoked Article 7 sanctioning procedures for the first time in December 2017. In September 2018, the European Parliament voted to launch Article 7 against Hungary for controlling media, restricting academic freedom, compromising the independence of the judiciary, and targeting civil society organizations. As in the case of Poland, the Council has yet to decide that there is a clear risk of a serious breach of EU values. Any sanctions that could follow would most likely be prevented by the Polish and Hungarian governments, respectively.

Seeking to circumvent political stalemate built into the Article 7 procedure, the European Commission has tried to interpret violations of fundamental 
values as noncompliance with the four freedoms of the Internal Market. This way it could open infringement proceedings against France for expelling Sinti and Roma in 2012 as a violation of the free movement of persons. The Commission also brought Hungary before the ECJ, which ruled against the Orbán government for violating the independence of the central bank and the data protection authority, as well as for changing the mandatory retirement age for judges.

More than sixty infringement proceedings related to the rule of law are still pending. Two of the most spectacular cases concern the attempt of Viktor Orbán to close down the Central European University in Budapest. Amid the unwillingness of the member states to consider the curbing of academic freedom as a threat to EU essential values, the Commission interpreted the changes in the Hungarian Higher Education Law as violations of the freedom to provide services and the freedom of establishment. ${ }^{8}$ Its invoking Article 7 for a serious breach of the rule of law notwithstanding, the Commission filed infringement proceedings against Poland over gender discrimination in the legal reforms Poland's ruling PiS party had initiated to seize control of the judiciary. One of the four controversial laws adopted by the Polish parliament set different retirement ages for female and male judges. The Commission asked the ECJ to issue an injunction in which the ECJ ordered Poland to halt its forced retirement of Polish Supreme Court judges and to restore all judges that had been forced out. ${ }^{9}$ After some initial defiance, the Polish government announced an amendment to the original law and reinstated the forced-out judges. ${ }^{10}$ In October 2019, however, the Commission referred Poland again to the ECJ over new disciplinary procedures and sanctions on ordinary court judges that would undermine their judicial independence from political control. ${ }^{11}$ The Commission launched yet another infringement proceeding against Poland in April 2020 for adopting a law that would allow Polish judges to be disciplined for referring cases to the ECJ. Only a few weeks before, the ECJ had suspended the activities of the newly created disciplinary board when it was about to waive the immunity of a Polish judge, a fierce PiS critic, to have him prosecuted for inviting reporters to a closed court hearing. ${ }^{12}$ The Polish government rejected the judgment immediately, arguing that the ECJ had no authority to assess the legality of constitutional bodies in a member state. Rather than responding to the EU's enforcement pressure, Warsaw and Budapest have used the Covid-19 pandemic as a pretext to further undermine the EU's fundamental principles by employing extraordinary emergency powers and compromising democratic elections, respectively. A major blow to the EU's legal order, however, came from the highest court of the most powerful member state. In May 2020, the German Constitutional Court dismissed the ruling of the ECJ on the legality of the European Central Bank's bond-buying scheme. Germany's top court considers the stimulus program beyond the ECB's power because the ECB did not 
prove that it took into account the broader economic effects of its bond-buying scheme (e.g., on people's savings or rents). Since the ECJ ruled in 2018 that the ECB's action conform with EU law, the German Constitutional Court explicitly challenges the primacy of EU law and the ECJ as its final arbiter. This could set a dangerous precedent for other national constitutional courts to defy the EU's authority to set and enforce law. At the same time, the decision of the German Constitutional Court may end, or at least seriously constrain, the member states' attempts to depoliticize controversial decisions by delegating them to independent EU bodies, such as the ECB.

In sum, the book covers violations of central parts of EU law around which European integration has emerged and where the EU (therefore) has developed a centralized compliance system. Budgetary rules or fundamental principles, including the rule of law, in contrast, have to be enforced by the member state governments, which have been reluctant to do so. The Commission has therefore sought to interpret legal obligations outside its enforcement authority as issues related to the Internal Market, making them subject to infringement proceedings. Transforming political rights, such as the freedom of the press, into market freedoms has allowed the Commission to circumvent member state control of enforcement. The diverging power of the member states to resist compliance remains, however, an issue. More importantly, Brussels bureaucrats directly interfering with decisions of democratically elected national parliaments to (re)design the separation of powers or to allocate social benefits risks politicizing the EU's authority to make and enforce laws. Populist parties in Hungary, Poland, Greece, Italy, and the UK have successfully mobilized the issue of popular sovereignty, contesting the EU's authority to enact laws even within its core purview (free movement of people). So does the German Constitutional Court when it challenges the ECJ's authority because the EU's top court did not curb the powers of the ECB in trying to keep the eurozone's economy afloat. This points to the limits of the $\mathrm{EU}$ as a regulatory polity and of regulatory governance beyond the nation state in general, to which I will return at the end of this chapter.

\section{De-centering the EU}

What does the EU teach us about noncompliance in international politics? The EU is often regarded as a system sui generis, whose unique supranational properties, including the supremacy and direct effect of EU law (Alter 2001), preclude generalizations to other international institutions. EU scholars and experts of other regions alike used to treat the EU as if it represented an $n$ of 1 , which required its own theories (Caporaso 1997; cf. Börzel 2013; Acharya 2016). Research on comparative regionalism has found that the EU exhibits an extraordinary degree 
of pooling and delegation of national sovereignty (Lenz and Marks 2016; cf. Hooghe et al. 2017). Compared to other regional organizations and international institutions, EU member states have relinquished ever more control over decision making, implementation, and dispute settlement. However, if we adopt a perspective that is fine-grained enough, any political institution will ultimately be one of its kind. Beyond the nation state, the EU is the most legalized system of governance in the world (Alter 2000, 490). At the same time, institutionalized mechanisms to manage and enforce compliance can be found in other international institutions, too (Mitchell 1996, 17-20; Smith 2000, 139-140; Peters 2003). This allows us to apply insights and theoretical arguments from the broader IR literature to the EU. The PCP model has four important implications for noncompliance with law beyond the nation state.

First, states with both weak capacity and strong power are compliance laggards and delimit the power of law beyond the nation state. They lack the bureaucratic quality to swiftly comply with international law and have the power to resist enforcement pressure. Studies differ in what they consider to be the source of state power in international institutions (Barnett and Duvall 2005; Baldwin 2016). The extent to which a state can use its superior military capabilities or the size of its economy and population to impose its preferences on others in international institutions is questionable, not only in the highly supranationalized EU (P. Haas 1998, 22-23; on the "fungibility problem" of power see Baldwin 2013, 278). At the same time, capabilities or resources often define the institutional power of a state (Barnett and Duvall 2005, 51-52). The permanent members of the United Nations Security Council are five nuclear powers. In the International Monetary Fund, the quota systems link financial contributions from member governments to their voting power. In the EU, the four largest member states pay more than 60 percent of the EU budget. While budget contributions are based on economic size (GDP), the votes in the Council of Ministers are weighted according to a member state's population. Even though the system has been skewed in favor of smaller member states, the four most populous member states, France, Germany, Italy, and the UK, used to have almost ten times more votes than Malta, whose population is less than 0.05 percent of the German population. Under the double majority rule introduced by the Lisbon Treaty's ordinary legislative procedure, population size still matters. Each member state has only one vote now. However, majority decisions require 55 percent of member states representing at least 65 percent of the EU population (Article 238 TFEU). The largest member states can block the adoption of EU laws in the Council. In other words, rather than weighted votes, it is the pooling of national sovereignty in the form of majority decisions that distinguishes the EU from other international institutions when it comes to the politics of noncompliance. Interestingly, though, 
many regional and international institutions, including the African Union, the Council of Europe, the Organization of the Petroleum Exporting Countries (OPEC), the World Trade Organization (WTO), and the World Health Organization (WHO), display a much higher degree of pooling than the EU (Hooghe et al. 2017, 128). In any event, the EU offers important insights on how institutional power affects the propensity of states to defect from their legal commitments that travel beyond Europe.

The EU's exceptionally high degree of delegation does not preclude generalization either. Monitoring and sanctioning may be more decentralized in the WTO, the North American Free Trade Agreement (NAFTA), or the West African Economic Community (ECOWAS). At the same time, the WTO, for instance, has authorized financial sanctions much more frequently than the EU, where the ECJ ruled on member states to pay lump sums for noncompliance only in a dozen or so cases. WTO penalties can also be much more severe in terms of their economic impact (Bronckers and Baetens 2013). This is not to deny that the delegation of enforcement authority is exceptional in the EU. However, if anything, this renders the $\mathrm{EU}$ a least likely case for the power to resist compliance. Big member states are able to resist EU enforcement pressures despite the strong authority and independence of the Commission and the ECJ in monitoring and sanctioning noncompliance. The EU puts claims about the importance of independent enforcement authorities into perspective.

Second, the twinning of management and enforcement is an effective way to restore compliance (Tallberg 2002, 632). The combination of managerial dialogue, capacity building, and penalties addresses the source of noncompliance identified by most compliance approaches. States need to be both willing and able to cope with compliance costs. The managerial instrument of capacity building, however, is not sufficient in restoring compliance if it merely entails the transfer of resources to noncompliant states. It is essential to foster bureaucratic efficiency, for instance by encouraging the establishment of coordination mechanisms and by promoting anticorruption measures as part of public-sector reforms. Bureaucratic efficiency is decisive for the capacity of states to absorb financial and technical assistance of international institutions. By promoting good-governance reforms, including the fight against corruption, international institutions can help reduce the risk of noncompliance (Dimitrova 2005; Börzel and van Hüllen 2014).

Third, politicization is on the rise, not only in the EU. The authority of international institutions is increasingly contested (Zürn, Binder, and Ecker-Ehrhardt 2012). National publics have become more and more aware of international institutions, such as the WTO, the International Criminal Court, or NATO, exercising authority. Public resistance against international authority has grown, too, 
resulting in opposing political preferences for international policies on free trade, financial regulation, climate change, or nuclear arms control. The politicization of international authority is likely to undermine compliance with international law, particularly by big states, such as the US, Russia, India, or Brazil. It may also affect the adoption of new international agreements. If concluded at all, they may become "thinner" (Downs, Rocke, and Barsoom 1996) or less demanding, once status quo and rising powers tie their hands to the growing public resistance against international authority. President Trump's attempt to renegotiate NAFTA into the United StatesMexico-Canada Agreement (USMCA) in the name of his "America First" policy, in whose name he also abandoned the Paris Agreement on climate change and the Iran nuclear deal, are only part of what many have described as a general crisis of the liberal international order (Ikenberry 2018; Zürn 2018; Lake, Martin, and Risse, 2021).

Fourth, the findings of the book highlight the regulatory nature of international law as a driver of noncompliance that has not received sufficient attention in the literature. IR approaches treat noncompliance as an issue of international cooperation. Defection is at the core of the collective-action problems that render agreement among states difficult even if they share common interests. In line with the functionalist-institutionalist thinking that has informed many IR theories, compliance approaches focus on institutional design. Enforcement prioritizes institutional mechanisms for monitoring and sanctioning, while management stresses capacity building and dispute settlement. Legitimacy, finally, points to international institutions as arenas of socialization. Consequently, IR theories have largely been used to account for variation in compliance across international institutions (Keohane, Moravcsik, and Slaughter 2000; Abbott et al. 2000). Since they diverge on assumptions about what motivates states to cooperate and defect, enforcement, management, and legitimacy approaches have been reformulated in a way to account for country-based explanatory factors, such as power (enforcement), capacity (management), and the acceptance of international rules and institutions (legitimacy). While international and domestic drivers of noncompliance are well understood, they are institutional and structural rather than policy related. There seems to be little variation as most international regimes and organizations make regulatory policy. The book, however, demonstrates that regulatory policy may vary with regard to the redistributive consequences that regulatory policy produces at the domestic level, making noncompliance more or less likely. Somewhat ironically, setting international standards aimed at correcting politically undesired market outcomes, such as social or environmental dumping, may be more likely to become politicized than classical market-making free trade agreements. In Europe, the latter fall under the exclusive competence of the EU. The former involve competencies, such as environment and consumer protection, which the EU shares with the member states. As "mixed agreements," 
they require ratification by all member states, which renders politicization, and thus ultimate failure, much more likely. The EU-Mercosur trade agreement, for instance, signed in June 2019 after twenty years of negotiations, will not only establish the largest free trade area in the world by removing tariffs. It will also strengthen workers' rights, improve environmental protection, uphold high food safety standards, and protect intellectual property rights. Nevertheless, the agreement faces major opposition in several member states, including France and Ireland.

In sum, institutional power, bureaucratic quality, and politicization are neither specific to EU market integration nor to the EU as a highly legalized international institution. The PCP model is general enough to capture noncompliance with all law beyond the state.

\section{The Politics of Noncompliance: Avenues for Future Research}

The findings of the book give rise to some suggestions for future research. It is important to disentangle specific variants of the different compliance approaches. Power matters mostly at the taking rather than the shaping stage. Moreover, instead of economic size and population per se, votes in the Council account for the power to resist enforcement pressure. Likewise, it is not the endowment with resources but the capacity of a government to mobilize them that is relevant for coping with costly EU laws. As the PCP model is based on a rational institutionalist framework, it has treated legitimacy variables only as controls. Bringing in politicization allows the model to account for the counterintuitive finding that more EU support correlates with more, not less, noncompliance. The causal mechanism is the ability of member state governments to tie their hands to Eurosceptic publics, which make the politicization of compliance costs more likely. Socialization and democratic accountability yield equally counterintuitive results. There are, however, other factors related to legitimacy, such as procedural fairness, support for the rule of law, or peer pressure. The literature has found little support for these variables. However, this may be related to the lack of time series data. There is room for a constructivist model of noncompliance that systematically explores the constitutive effect of norms, such as the rule of law, the role of socialization processes at the EU level, or the relevance of cultural factors at the domestic level.

Within its rational institutionalist framework, the PCP model neglects a number of factors, owing to the liberal intergovernmentalist conceptualization of the link between the EU and the member state level. While domestic actors 
influence the formulation of policy preferences, member state governments gatekeep access to EU negotiations. We know that organized interests, companies, and citizens are an important part of the EU's decentralized monitoring system providing the Commission with information about possible violations of EU law. They can also block or at least delay compliance when they mobilize against costly EU laws. However, to what extent do they directly interfere with the compliance game, seeking to prevent costly EU laws or at least lower their compliance costs? Likewise, the literature has focused on pro-compliance coalitions at the domestic level, which try to push their governments toward compliance, raising the costs of noncompliance at the taking stage. To what extent do domestic actors seeking to extend their rights under EU law already interfere at the shaping stage, through allying with the Commission as the key agenda setter, as suggested by supranational institutionalist theories of European integration (Sandholtz and Stone Sweet 1998; Pollack 1997b)? Finally, what about the courts of the member states? They are obliged to enforce EU laws, even if those laws contradict existing national legislation. This may empower lower domestic courts vis-à-vis their superior courts because they have the right to directly address the ECJ for a ruling on the compatibility of EU and national law (Burley and Mattli 1993; Alter 2001; Conant 2002). Domestic courts provide important arenas for the legal internalization of EU law in the member states (Koh 1996; Panke 2007). At the same time, their effectiveness depends on the mobilization of societal actors that use legal claims to pressure for the necessary domestic changes to ensure rule-consistent behavior (Conant 2002; Cichowski 2007; Kelemen 2006), as well as their own capacity to deal with the legal claims (Dyevre, Glavina, and Atanasova 2019). Rather than treating preliminary rulings as an alternative measurement of noncompliance with EU law, though, it could be fruitful to investigate whether preliminary rulings increase the chances of noncompliance by making EU laws costlier after their adoption or whether they bring noncompliance down by socializing domestic actors. Finally, the dismissal by the German Constitutional Court of the ECJ decision on the ECB's bondbuying power, which the German Constitutional Court itself had sought from the ECJ, indicates that preliminary ruling may become an object of noncompliance rather than work as a mechanism to induce compliance. Future research should explore more society-centered models of noncompliance, which give domestic and transnational actors a greater role beyond influencing national preference formation at the shaping stage and acting as potential veto players at the taking stage. De-centering national governments could also involve unpacking national parliaments. Compliance research has started to explore the role of party composition, electoral rules, and institutional culture for noncompliance with EU law (Steunenberg 2006; König and Luetgert 2009; König 2007; Luetgert and 
Dannwolf 2009; Sprungk 2011; Auel and Raunio 2014; Auel, Eisele, and Kinski 2016). It would be interesting to see whether these factors influence the degree to which national parliaments politicize compliance costs. This could also help explain why some costly market-correcting EU laws become more politicized than others. One issue-related factor could be the concentration of compliance costs (Siegel 2011). These are much more concentrated, for example, in the case of the fauna, flora, habitat directive as compared to the directive on the quality of water intended for human consumption.

This book demonstrates that different compliance approaches can and should be combined to account for variation in noncompliance across countries, time, and policy sectors. Across the board, countries with high power (to be recalcitrant) are more likely to violate EU law than less powerful ones. Countries with inefficient administrations are worse compliers than those of high bureaucratic quality, no matter what legal act they have to transpose, implement, and enforce. Likewise, all member states violate legal acts in market-correcting policy sectors more often than legislation in policy sectors that are mostly aimed at market making. Also, all member states infringe on new EU legal act more often than on amending and delegated legislation. The PCP model specifies how these country-, policy-, and rule-specific characteristics jointly affect noncompliance at the two different stages of the compliance game. At the same time, the PCP model suggests potential interaction effects that are supported by the empirical findings. Politicization reduces the positive effect of power and enhances the negative effect of capacity on noncompliance. Figure A5.1 in appendix 5 exemplifies the interactions of voting power, bureaucratic quality, and opposition to the EU (Euroscepticism). The plot shows that voting power increases the number of reasoned opinions - the slope and the level of this effect, however, vary depending on the level of bureaucratic quality and Euroscepticism. Member states with high bureaucratic quality and Eurosceptic publics comply quite well, even when they wield substantial voting power in the Council. This is even the case (although to a lesser extent) for countries with low bureaucratic quality and Eurosceptic publics (middle line). The impact of voting power on noncompliance is greatest, as expected, in member states with low bureaucratic quality, Euro-supportive publics, and strong voting power. Similar interaction effects may be observed between EU institutions, policy sector, and politicization. If market-correcting policy is more likely to be violated because its compliance costs are more visible and salient, a higher number of political constraints should magnify the positive effect of market-correcting policy on noncompliance. Delegated legislation, in contrast, should reduce this positive effect, since the lack of parliamentary involvement renders the politicization of compliance costs less likely. The empirical testing 
of the PCP model also yields some findings that point to possible interaction or conditional effects that may lie outside its explanatory logic. In the EU-25 model, for instance, some variables, such as EU support and regional authority, change their sign and/or significance (see chapter 3). There is nothing in the PCP model to suggest that the effect of EU support or opposition on noncompliance is conditional upon a factor that systematically varies between old and new member states.

Finally, the PCP model is generalizable enough to explain noncompliance in other regional and international organizations. However, there is one caveat. Even though there is a gap in power and capacity between most of the old and most of the new member states, the EU consists of a group of relatively homogeneous states, which face a globally unique level of political and economic integration. The membership of other international organizations and regional integration projects, such as the Association of Southeast Asian Nations (ASEAN) or NAFTA/ USMCA, is much more heterogeneous in terms of economic size, resources, or bureaucratic quality (compare the US and Mexico within NAFTA/USMCA). This applies even more to the regime types of member states, their economic development, and their respect for the rule of law and human rights. This book could not explore the role of these potential background variables since they are largely constant within the data set. Future research should focus on these factors and inquire whether they affect the explanatory value of the PCP model and to what extent they account for unexplained variation.

\section{The Limits of Regulatory Governance beyond the State}

The EU governs the largest market in the world. It does so through the adoption of market-making and market-correcting regulation. Rather than directly providing public goods and services, the EU regulates states, private actors, and markets. Accordingly, Majone has described the EU as a "regulatory state," which lacks the power to make truly (re)distributive policy (Majone 1993, 1994). With the subsequent deepening and broadening of its regulatory authority, the EU has established a comprehensive regulatory framework that has successfully prevented and corrected market failures (Eckert 2015; Finger 2011). Besides opening national markets to foreign competition by eliminating tariffs, taxes, quotas, and other protectionist policies, such as state subsidies, EU law has broken up state monopolies as they traditionally existed for utilities, such as telecommunications or energy. It has also created a level playing field for suppliers and consumers by harmonizing standards on the quality, safety, and labeling of products and 
production processes (e.g., regulations on food standards, packaging, the use of chemicals, working hours).

When it came to developing the Internal Market into an EMU, the EU opted again for a regulatory approach. Despite the massive (re)distributive implications of a common currency, this was arguably the only way to give the EU any authority over core state powers, such as fiscal policy (Genschel and Jachtenfuchs 2016). Shifting costs to the domestic level facilitated agreement at the EU level. An equal distribution of costs suggested by imposing uniform legal obligations on all member states promised to mitigate the risk of politicization.

Not surprisingly then, the multiple crises the EU has faced over the past decade are often considered a regulatory failure (Jachtenfuchs 2018), a major cause of which is noncompliance. Indeed, member states had violated EMU rules even before they were hit by the collapse of US investment banks in 2008. They also broke the Schengen rules long before the historic influx of refugees and migrants in 2015. However, as this book suggests, a certain level of noncompliance does not necessarily undermine the functioning of the $\mathrm{EU}$. In fact, a polity seeking to integrate a growing number of states, which are ever more heterogeneous with regard to their policy preferences, power, capacity, and politicization, may need a certain amount of noncompliance or "institutionalized hypocrisy" (Iankova and Katzenstein 2003) to allow for the flexibility necessary to balance unity and diversity. Similar to escape clauses or safeguards in international treaties, noncompliance provides the necessary flexibility to prevent the breakup of otherwise too rigid regulatory arrangements (Rosendorff and Milner 2001; Pelc 2009). In other words, noncompliance ain't always a bad thing. It only turns into a systemic risk when states refuse to incur compliance costs altogether by contesting the authority of the Commission as the guardian of the treaty, the ECJ as its ultimate umpire, or the validity of EU law as such.

With the euro and the migration crises, noncompliance has gained a new quality in the EU-it has become a way for member states to dodge the costs of redistribution, which regulatory policy shifts to the domestic level, where costs become politicized. Accordingly, noncompliance with euro and Schengen rules differs from the noncompliance analyzed in this book in three important ways. First, by establishing a common currency and abolishing border controls, member states have given up rather than transferred authority to the EU level. EMU deprives euro countries of key instruments of macroeconomic management without creating a common fiscal and economic policy. The EU is a monetary but not an economic union. Likewise, the Schengen states did away with internal border controls but have refused to set up common external border controls and common rules and procedures to handle asylum seekers and refugees. This is different from traditional regulatory policy, which seeks to establish 
and enforce common EU regulations to correct market failure and politically undesired outcomes. Second, compliance costs are not evenly distributed among states. Export-led economies, including Germany and the Netherlands, have less difficulty with the budgetary rules of the Stability and Growth Pact than the demand-led economies of France, Italy, or Greece, which rely on deficit spending to generate growth and employment (Scharpf 2016a). Likewise, in immigration, frontline states (Greece, Italy, Spain) as well as target countries (Germany, Austria, Sweden) face greater challenges than transit countries in meeting the requirements of the Dublin regime, because of the much higher number of refugees and migrants they have to cope with (see chapter 5). Third, the euro and Schengen are about identity politics. The political controversies over the euro crisis have centered predominantly on questions of order-that is, what constitutes Europe as a community, and how much solidarity members of the community owe to each other and under which conditions. The mass influx of migrants and refugees changed identity politics into questions of borders: who belongs to Europe as a community, with Eurosceptic populist parties advocating for an exclusionary fortress Europe (Börzel and Risse 2018).

These differences explain why compliance with EU law has become increasingly politicized. Nationalist populist politicians do not only resent the euro and Schengen. Viktor Orbán, Marine Le Pen, Jarosław Kaczyński, Alexander Gauland, Geert Wilders, or Nigel Farage deny the EU the authority to make and enforce rules on issues that interfere with national sovereignty, which could also include large-scale logging in one of Europe's last primeval forests in Poland. ${ }^{13}$ This is not the place to discuss the rise of nationalist populism in Europe and other parts of the world (cf. Hutter, Grande, and Kriesi 2016; Hooghe and Marks 2018). There is little doubt that the politicization of international authority will continue. The findings of the book indicate that politicization is likely to intensify if governments seek to mask and address redistributive issues as regulatory problems, which require stricter rules and tougher enforcement. CEE member states shirking their obligation to take in refugees under the temporary relocation mechanisms adopted in 2015 is a case in point (see chapter 5). Germany dragging its feet in setting up the Single Resolution Fund (SRF) is another. The Banking Union, established after the financial crisis of 2008, prohibits the bailing out of insolvent banks by states. The Single Resolution Mechanism (SRM) and SRF are intended to regulate and finance the restructuring of troubled banks (de Rynk 2016). Yet the German government anticipates major opposition to German banks bailing out banks of crisis countries, which is one of the reasons why the SRF is still not operational. As a result, the Italian government had to use $€ 17$ billion of its taxpayers' money to rescue two of its major banks, which the ECB had sent into insolvency proceedings. The intervention violates a core 
rule of the Banking Union that private creditors have to cover bank failure costs, rather than taxpayers. The Commission approved the state aid for the liquidation of the two Italian banks because of the serious economic impact their breakdown would have had. ${ }^{14}$

The UK's decision as the first member state ever to leave the EU could be seen as the ultimate act of systemic noncompliance. No other member state has obtained so many opt-outs (see chapter 4). Still, 51.9 percent of the British electorate chose exit over voice. Rather than a massive declaration of noncompliance with core principles of the EU, such as the free movement of people, Brexit seems the logical continuation of the UK's approach to avoid legal obligations the majority of British citizens would not want to comply with. In light of the consistently low support for EU membership and the exemplary compliance record, this seems to be only consequential. Tying hands has reached its limits. The other member states have not been willing to reduce the European integration project to the regulation of free trade in goods and financial services. At the same time, many of them do not seem to be willing to comply with essential EU laws that go beyond regulating markets. While this seems paradoxical, it has to do with the limits of EU regulatory governance.

A common policy on refugees, asylum seekers, and migrants is the flip side of the free movement of people in a borderless Europe. Likewise, a common currency as the next step of economic integration requires some common economic and fiscal policy to ensure the necessary convergence of national economies. More regulatory governance is not only inadequate to deal with the ensuing redistributive conflicts that come with such common policies (Majone 1994). Seeking to mask the allocation of adjustment costs or refugees as a regulatory issue undermines both the effectiveness and the legitimacy of EU governance. The EU's failure in the financial crisis to recognize the need for a different governance mix to tackle redistribution that does not rely on non-majoritarian supranational institutions has further politicized the EU as a system of governance. Its democratic credentials are not only questioned by populist politicians and citizens rallying against the socioeconomic effects of the financial and the migration crises (Börzel 2016). The constitutional courts of several member states have also reserved the right to review and, if necessary, nullify changes in the EU's governance mix, by which EU law is allowed to override the will of the majority produced by democratic elections (Fabbrini 2014; Joerges 2016). The German Constitutional Court has been the first to do so. Germany's top court nullified the ECJ decision that the ECB had acted within its power with its bond-buying scheme. Thereby, it not only challenged the ECJ's exclusive right to rule on EU institutions and interpret EU law. It may also put a stop to the member states relying on the ECB to offset economic shocks because of their own unwillingness to raise and allocate the necessary 
financial resources. The member states' attempt to depoliticize redistributive issues through delegating them to supranational institutions has backfired. The delegation of more political authority to the ECB, the Commission, or the European Border and Coast Guard to avoid or escape politicization at the domestic level has fueled opposition to an increasingly intrusive and undemocratic EU and empowered Eurosceptic populist forces at both ends of the political spectrum (Börzel and Risse 2018). Abolishing or severely constraining national sovereignty can be no longer legitimized by the need to strengthen the EU's problem-solving capacity. On the contrary, delegating authority to ensure compliance with controversial EU law is not only likely to result in more (fundamental) violations of EU law, particularly if there is increasing disagreement among member state governments (König and Mäder 2013, 2014b). It also undermines public support of the EU as a whole (Fjelstul and Carrubba 2018).

There is neither the political will nor the public support for creating a genuine social and political union, which would have the legal and fiscal authority to protect and support specific social rights (Habermas 2013) of both EU citizens and third-country nationals in need of protection. The controversy over "corona bonds" to finance the EU's emergency and recovery measures in managing the Covid-19 pandemic illustrates one more time that member states are unwilling to develop a common fiscal policy to cope with external shocks. The $€ 0.5$ trillion infusion to help governments, businesses, and workers to cope with economic crisis will be funded through the European Stability Mechanism, the European Investment Bank, and the Pandemic Emergency Purchase Programme of the ECB. The disagreement, notably between France and Germany, on giving the $\mathrm{EU}$ more redistributive power, at least partly explains why the EU has become a monetary but not an economic union (Dyson 1994). The debate on how to strengthen the eurozone indicates that the disagreement continues to exist more than fifteen years after the Maastricht Treaty created the Economic and Monetary Union. The proposals for a euro finance ministry with its own budget to strengthen the euro zone are not new. Since the proposal was taken up by France's President Emmanuel Macron in 2017, Germany no longer outright rejects the idea. However, rather than a way to kick-start the economies of Southern European crisis countries through European investments, Germany conceives of the euro finance minister as another institution to supervise and enforce solid budget management in these countries. The EU agreement on a USD $\$ 870$ billion stimulus package to cope with the COVID-19 pandemic notwithstanding, the persisting lack of consensus between Germany and France on a European social model is a major impediment to EU redistributive policy. Attempts to establish a common asylum system have equally stalled as member states cannot agree on whether and how to share the responsibility for receiving and integrating people seeking international protection (Börzel 2020). 
The EU is likely to remain what it used to be good at—a regulatory state. What has been undermining its effectiveness and legitimacy is not so much the lack of redistributive authority. While its regulatory institutions constrain the member states in their redistributive capacity, the problem lies in the attempt of member state governments to depoliticize redistributive issues by delegating them to independent regulatory agencies, such as the Commission, the European Central Bank, or the European Border and Coast Guard. Ironically, this has ultimately led, at the domestic level, to more rather than less politicization that contests not only specific EU policy but the authority and legitimacy of the EU as such (Börzel 2016; Börzel and Risse 2018).

While being an extreme case of regulatory governance beyond the state, the $\mathrm{EU}$ offers some important lessons to other international institutions. Rising public resistance against deep and comprehensive international trade and investment agreements, such as CETA, TPP, or TTIP, which are not only about market making but entail some substantial elements of market correction (Kim, Mansfield, and Millner 2016), clearly demonstrate that the compliance costs of regulatory policy are redistributive and increasingly likely to be politicized. Rather than masking redistribution as a regulatory problem to be best delegated to independent agencies, such as investor state dispute settlement bodies or international courts, national policy makers may have to engage in public debates about who should get what within and beyond the nation state. National parliaments could play a key role in this regard. The book has found them to be agents of politicization by increasing the salience of the EU and its policies. However, this does not necessarily have to result in policy blockage and noncompliance (Auel, Eisele, and Kinski 2016). Public debates about the EU and EU policies can increase democratic accountability (Auel 2007; Auel and Höing 2015) and thus the legitimacy of the EU, thereby fostering voluntary compliance. The EU has to start relying on the social acceptance of its citizens to ensure compliance. 